\title{
Detecção de genes toxigênicos em amostras de Staphylococcus spp. isoladas de queijos de coalho
}

\author{
Detection of toxigenic genes in samples of Staphylococcus spp. \\ isolated from rennet cheese
}

\author{
Manuela Figueiroa Lyra de FREITAS ${ }^{1}$, Isabelle da Silva LUZ ${ }^{2}$, José Wilton PINHEIRO JÚNIOR ${ }^{3}$, \\ Dalila Angélica Moliterno DUARTE 4 , Ana Mercia Mendes VASCONCELOS ${ }^{4}$, Aldemir Reginato RIBEIRO 4 , \\ Rinaldo Aparecido MOTA ${ }^{5 *}$, Tereza Cristina Leal BALBINO ${ }^{6}$, Tânia Lúcia Montenegro STAMFORD ${ }^{7}$
}

\section{Resumo}

Objetivou-se com este trabalho isolar quantificar e investigar em amostras de Staphylococcus spp. isoladas de queijos de coalho, a presença dos genes toxigênicos sea-see, seg-sej, tst, eta e etb através da Reação em Cadeia da Polimerase (PCR). Foram verificadas contagens de Staphylococcus coagulase positiva (SCP) variando de $10^{2}$ a $10^{6} \mathrm{UFC} \cdot \mathrm{g}^{-1}$. Os genes toxigênicos tst, sec, sed, seg, seh, sei e sej foram identificados em 18 dos 20 isolados de Staphylococcus spp. com os seguintes percentuais 5, 11, 9, 20, 16, 25 e 14\% respectivamente. A presença de elevado percentual de isolados contendo diferentes genes toxigênicos é preocupante para a saúde do consumidor pela possibilidade de produzirem toxinas responsáveis por intoxicações alimentares. A ocorrência de vários genes toxigênicos em amostras de Staphylococcus coagulase negativa é outro fato importante, pois no Brasil não existe legislação com determinação de limites para Staphylococcus coagulase negativa em alimentos.

Palavras-chave: queijo coalho; PCR; enterotoxina.

\begin{abstract}
The aim of this study was to isolate, quantify, and investigate samples of Staphylococcus spp from rennet or coalho cheese (a firm but very lightweight cheese produced in Brazil) and determine the presence of the toxigenic genes sea-see, seg-sej, tst, eta, and etb by the polymerase chain reaction (PCR). Counts of coagulase-positive Staphylococcus (CPS) were found varying from $10^{2}$ to $10^{6} \mathrm{CFU}^{-1}$. The toxigenic genes tst, sec, sed, seg, seh, sei, and sej were identified in 18 of the 20 isolates of Staphylococcus spp at the following percentages: 5, 11, 9, 20, 16, 25, and $14 \%$, respectively. The presence of a high percentage of isolates containing different toxigenic genes is a matter of concern for the health of the consumer due to the possible production of toxins responsible for food poisoning. The presence of various toxigenic genes in samples of coagulase-negative Staphylococcus is another important fact because there are no laws in Brazil regarding limitations on the presence of coagulase-negative Staphylococcus in foods.

Key words: rennet cheese; PCR; enterotoxin.
\end{abstract}

\section{Introdução}

O queijo de coalho é um dos mais tradicionais queijos produzidos no Nordeste brasileiro e devido a sua produção artesanal, é amplamente fabricado nesta região. É também um importante derivado do leite, apreciado tanto pelo seu valor nutritivo como pelo seu sabor. No entanto, as condições de processamento, armazenamento e comercialização podem comprometer suas características organolépticas, bem como, torná-lo impróprio para consumo, em virtude da contaminação por microrganismos responsáveis por toxinfecções alimentares (SÁ et al., 2003).
Elevados índices de Staphylococcus aureus ocorrem em queijos, tanto no Brasil (HOFFMANN; SILVA; VINTURIM, 2002) como em outros países do mundo (NORMANNO et al., 2005), incluindo cepas de estafilococos enterotoxigênicos. Por isso, o queijo ocupa lugar de destaque entre os produtos lácteos envolvidos em surtos de doenças de origem alimentar, veiculando principalmente Staphylococcus spp. (VERAS et al., 2003).

Sendo o queijo de coalho um alimento muito consumido no Estado de Pernambuco, objetivou-se com este trabalho realizar

Recebido para publicação em 3/10/2007

Aceito para publicação em 22/1/2008 (002903)

${ }^{1}$ Centro Acadêmico de Vitóra, Universidade Federal de Pernambuco - UFPE, Rua do Alto do Reservatório, s/n, Bela Vista, Vitória de Santo Antão - PE, CEP 55608-680;

E-mail: manuelaflf@uol.com.br

${ }^{2}$ Centro de Pesquisas Aggeu Magalhães, Avenida Professor Moraes Rego, s/n, Cidade Universitária, Recife - PE, CEP 50670-420, CP 7472

3 Unidade Acadêmica de Garanhuns, Universidade Federal Rural de Pernambuco - UFRP, Av. Bom Pastor, s/n, Boa Vista, CEP 55296-901, Garanhuns - PE,

E-mail: jrwilton@uag.ufrpe.br

${ }^{4}$ Setor de Microbiologia, LANAGRO - PE

${ }_{5}^{5}$ Departamento de Medicina Veterinária, Universidade Federal Rural de Pernambuco - UFRP, Rua Dom Manuel, s/n, Dois Irmãos, CEP 52171-900, Recife - PE, E-mail: canjani_ch@hotmail.com

${ }^{6}$ Centro de Pesquisas Aggeu Magalhães, Professor Moraes Rego, s/n, Cidade Universitária, Recife - PE, CEP 50670-420, CP 7472

Departamento de Nutrição, Universidade Federal de Pernambuco - UFPE, Avenida Professor Moraes Rego, 1235, Cidade Universitária, Recife - PE, CEP 50670-901

${ }^{*}$ A quem a correspondência deve ser enviada 
o isolamento e quantificação de Staphylococcus spp. e investigar a presença de genes toxigênicos utilizando a técnica de PCR.

\section{Material e métodos}

Foram analisados 20 isolados de Staphylococcus spp. de dez amostras de queijos de coalho comercializadas no Estado de Pernambuco, seguindo o método preconizado pela Coordenação de Laboratório Animal (CLA) do Ministério da Agricultura Pecuária e Abastecimento - MAPA. O cálculo para contagem das unidades formadoras de colônias (UFC/g) foi realizado em função do número de colônias típicas e atípicas contadas, diluição inoculada e percentual de colônias confirmadas (BRASIL, 2003).

Para a identificação dos estafilococos foram verificadas características morfotintoriais das colônias em ágar base acrescido de $8 \%$ de sangue desfibrinado de carneiro e coloração pela técnica de Gram, produção de hemólise e provas bioquímicas como catalase, coagulase, termonuclease, fermentação da glicose em anaerobiose, fermentação do manitol em aerobiose e anaerobiose e produção de acetoína. Após a realização dos testes, os isolados foram identificados como Staphylococcus aureus, Staphylococcus coagulase positiva (SCP) e Staphylococcus coagulase negativa (SCN).

O DNA genômico dos Staphylococcus spp. foi extraído de acordo com Fritsch, Maniatis e Sambrook (1989) e quantificado no programa 1D Image Analysis, version 3.5 da Kodak Digital Science, DC 120 zoom Digital Câmera, após eletroforese em gel de agarose a $1 \%$, usando-se o DNA do fago $\lambda$ clivado com a enzima HindШ.

Para a pesquisa dos genes toxigênicos foram realizadas duas reações de PCR-Multiplex, uma para pesquisa dos genes sea, seb, sec, sed e see e outra para pesquisa dos genes eta, etb e $t s t$, bem como, quatro reações de PCR-Uniplex para a pesquisa dos genes seg, seh, sei e sej. Os primers para as reações de PCR foram sintetizados tendo como base as sequências publicadas por Becker, Roth e Peters (1998), Rosec e Gigaud (2002) e Omoe et al. (2002) (Tabela 1).

As reações de PCR-Multiplex foram preparadas para um volume final de $25 \mu \mathrm{L}$ contendo $20 \mathrm{pmol}$ de cada primer, $10 \mathrm{mM}$ Tris- $\mathrm{HCl}$ pH 9.0, $50 \mathrm{mM}$ de KCl, $160 \mu \mathrm{M}$ de cada dNTP, $3 \mathrm{mM}$ de $\mathrm{MgCl}_{2}, 20$ ng de DNA genômico e 1,2U da Taq DNA polimerase (Invitrogen, Brasil). As amplificações foram realizadas em termociclador (Biometra) programado para 30 ciclos térmicos, cada um consistindo de $95^{\circ} \mathrm{C}$ por 1 minuto (desnaturação), $55^{\circ} \mathrm{C}$ por 1 minuto (anelamento) e $72{ }^{\circ} \mathrm{C}$ por 2 minutos (extensão). Foram usados como controle a cepa padrão de $S$. aureus FRI MN 8 (Food Research Institute Madison, Wiscosin, EUA) portadora do gene tst e FRI 361 portadora dos genes sec e sed.

As reações de PCR-Uniplex para a pesquisa dos genes seg, seh, sei e $s e j$, separadamente, consistiu de uma mistura de $20 \mathrm{pmol}$ de

Tabela 1. Primers usados para a detecção por PCR dos genes sea-see, seg-sej, tst, eta e etb em Staphylococcus spp. isolados de amostras de queijos de coalho no Estado de Pernambuco, Brasil.

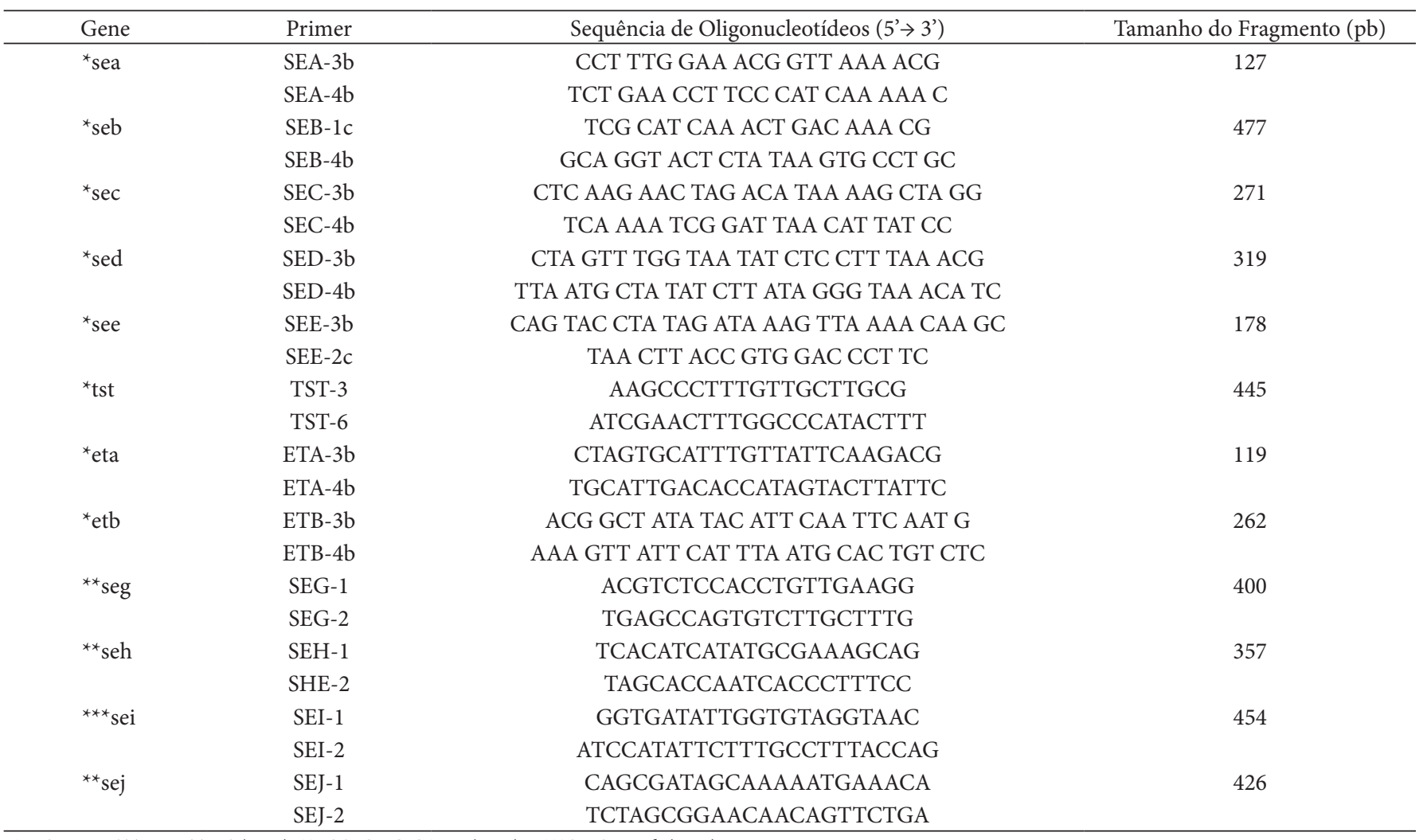

*BECKER, ROTH e PETERS (1998); ${ }^{* *}$ ROSEC e GIGAUD (2002); e ***OMOE et al. (2002). 
cada primer, $160 \mu \mathrm{M}$ de cada dNTP, $1,5 \mathrm{mM}$ do $\mathrm{MgCl}_{2}, 10 \mathrm{mM}$ do Tris-HCl pH 9.0, $50 \mathrm{mM}$ de KCl, 20 ng do DNA genômico e $1 \mathrm{U}$ da Taq DNA polimerase (Invitrogen, Brasil) em um volume final de $25 \mu \mathrm{L}$. As amplificações para os genes seg, seh e sej foram realizadas em termociclador (Biometra) programado para 30 ciclos térmicos, cada um consistindo de $94^{\circ} \mathrm{C}$ por 3 minutos, $94^{\circ} \mathrm{C}$ por 30 segundos, $60^{\circ} \mathrm{C}$ por 30 segundos e $72{ }^{\circ} \mathrm{C}$ por 30 segundos. A amplificação do fragmento para o gene sei foi programada para $94{ }^{\circ} \mathrm{C}$ por 30 segundos, $60^{\circ} \mathrm{C}$ por 30 segundos e $72^{\circ} \mathrm{C}$ por 60 segundos. Foi usada para controle a cepa padrão de $S$. aureus FRI 361 portadora dos genes seg, sei e sej.

Os produtos de amplificação das reações de PCR foram analisados por eletroforese em gel de agarose $1,5 \%(\mathrm{~m} / \mathrm{v})$, corados com brometo de etídeo $(10 \mathrm{mg} / \mathrm{mL})$ por 15 minutos, visualizados e fotografados em transiluminador de UV. Para confirmar se os segmentos amplificados pela PCR faziam parte dos genes $t s t, s e c$, sed, seg, seh, sei e sej o padrão de restrição dos fragmentos foi obtido. A enzima RsaI foi selecionada para a digestão dos fragmentos amplificados pela PCR dos genes seg e sej e a enzima DraI para o gene seh, de acordo com Rosec e Gigaud (2002). Avaliando-se os sítios de restrição através do programa Generunner DNA Sequence Analyses software, versão 3.05 disponível gratuitamente na rede, a enzima RsaI foi utilizada para a digestão dos fragmentos amplificados pela PCR dos genes sec, sed e sei e a DraI para o gene tst. O tamanho dos fragmentos obtidos após restrição foi analisado após eletroforese em gel de agarose $1,8 \%$.

Para confirmar que o segmento amplificado era parte dos genes tst, sec, sed, seg, seh, sei e sej os segmentos foram purificados com o kit PureLink PCR Purification (Invitrogen, Brasil) e analisados através do sequenciador automático ABI 3100 (Applied Biosystem, USA). As sequências dos nucleotídeos obtidas foram analisadas pelo programa Agrupamento das sequências de S. aureus - forward e reverse (HUANG; MADAN, 1999) e comparadas com sequências depositadas no GenBank versão 2.2.12 do programa Blast (ALTSCHUL et al., 1990).

\section{Resultados e discussão}

Das 20 amostras de Staphylococcus spp. estudadas, 11 (55\%) foram identificadas como S. aureus, seis (30\%) como SCP e três (15\%) como SCN. As contagens de Staphylococcus coagulase positiva nas dez amostras de queijos de coalho variaram de $10^{2}$ a $10^{6} \mathrm{UFC} / \mathrm{g}$. Resultados semelhantes foram encontrados por SENA (2000) que verificou contagens variando de $10^{3}$ a $10^{7} \mathrm{UFC} / \mathrm{g}$ em queijos de coalho em Recife e por BARBOSA et al. (2004) que encontraram contagens de $10^{3}$ a $10^{6} \mathrm{UFC} / \mathrm{g}$ em queijos de coalho comercializados em Teresina.

De acordo com a resolução RDC $\mathrm{n}^{\circ} 12$, de 2 de janeiro de 2001 (BRASIL, 2001), o limite padrão para a contagem de Staphylococcus coagulase positiva em queijo de coalho é de $5 \times 10^{3} \mathrm{UFC} / \mathrm{g}$. Das dez amostras analisadas, nove (90\%) estavam com valores superiores ao padrão estabelecido. Estes achados corroboram com os de Sá et al. (2003) que também relataram elevados índices de amostras de queijos fora do padrão.

O S. aureus é um patógeno responsável por intoxicações que resultam da ingestão de alimentos contaminados por enterotoxinas termoestáveis e pré-formadas (SU; WONG, 1997) e representa um risco sanitário quando níveis desta bactéria atingem contagens em torno de $10^{5}$ a $10^{6} \mathrm{UFC/g}$ ou $\mathrm{mL}$ no alimento (JABLONSKI; BOHACH 1997). Neste estudo, 60\% das amostras de queijo de coalho apresentaram contagens em torno de $10^{5}$ a $10^{6} \mathrm{UFC} / \mathrm{g}$.

No que se refere à pesquisa de genes toxigênicos, constatouse que $10 \%$ das amostras não apresentaram nenhum dos genes toxigênicos sea-see, seg, seh, sei, sej, tst, eta e etb e $90 \%$ foram positivas para um ou mais genes toxigênicos. A frequência dos genes toxigênicos em Staphylococcus spp. foi: seg (20\%); seh (16\%); sei (25\%); sej (14\%); sec (11\%); sed (9\%); e tst (5\%). No entanto, não se observou a presença de genes para as toxinas estafilocócicas SEA, SEB, SEE, ETA e ETB em nenhuma das amostras de Staphylococcus spp. estudadas.

Das amostras que apresentaram genes toxigênicos, $11 \%$ portavam apenas um gene, $11 \%$ dois genes, $45 \%$ três genes, $11 \%$ cinco genes e $22 \%$ seis genes, verificando-se os seguintes genótipos: tst $1 / 18$ isoladamente; sei $1 / 18$ isoladamente; $2 / 18$ a associação $(s e h+s e i)$ e $5 / 18$ as associações $(s e g+s e i+s e j) ; 1 / 18$ $(t s t+s e g+s e h) ; 1 / 18(s e c+s e d+s e i) ; 1 / 18(s e g+s e h+s e i) ; 1 / 18$ $(s e c+t s t+s e g+s e h+s e i) ; 1 / 18(s e c+s e d+s e g+s e h+s e i) ; 4 / 18$ $(s e c+s e d+s e g+s e h+s e i+s e j)$.

Dos três isolados de Staphylococcus coagulase negativa, um apresentou o genótipo $(s e h+s e i)$ e dois o genótipo $(s e c+s e d+$ $s e g+s e h+s e i+s e j)$. Alguns estudos demonstraram que SEC e SED estão associadas com contaminação animal, enquanto SEA e SEB à contaminação humana (BERGDOLL, 1990; RODRIGUES et al., 1993; SU et al., 1998). Jorgensen et al. (2005) constataram que $69 \%$ das cepas de S.aureus portavam os genes toxigênicos tst, sea, sec, seg, seh e sei e Loncarevic et al. (2005) demonstraram que $34 \%$ das cepas continham os genes seb, sec, sed, seg, seh, sei e sej, sendo estes resultados condizentes aos encontrados neste estudo, exceto pela ausência dos genes sea e seb, e a presença do gene see que não foi encontrado neste estudo.

A análise dos resultados utilizando o programa Blast revelou homologia superior a $90 \%$ entre os genes tst, sec, sed, seg, seh, sei e sej entre os isolados estudados quando comparadas com sequências depositadas no GenBank. A comparação dos fragmentos por eletroforese em gel de agarose dos genes tst, sec, sed, seg, seh, sei e sej amplificados nas diferentes cepas e digeridos com as enzimas RsaI e DraI, revelou um padrão de restrição esperado e idêntico entre os isolados para cada gene estudado (Figura 1). Estes resultados são confirmatórios da presença dos genes tst, sec, sed, seg, seh, sei e sej em amostras de Staphylococcus coagulase positiva e negativa.

Ao avaliar a presença dos genes seg, seh, sei e sej para as novas toxinas nos isolados de queijos de coalho, verificou-se que os genes mais frequentes foram o seg e sei. Estes achados são similares aos relatados por Loncarevic et al. (2005). Este fato é importante, pois tais cepas podem produzir as toxinas SEG e SEI e determinarem intoxicação alimentar, pois ao utilizar a técnica de PCR para estudar os genes seg, seh e sei em cepas de $S$. aureus de indivíduos envolvidos em casos de doenças de origem alimentar, Chen, Chiou e Tsen (2004) verificaram que em um dos pacientes a cepa de $S$. aureus isolada portava apenas 
A

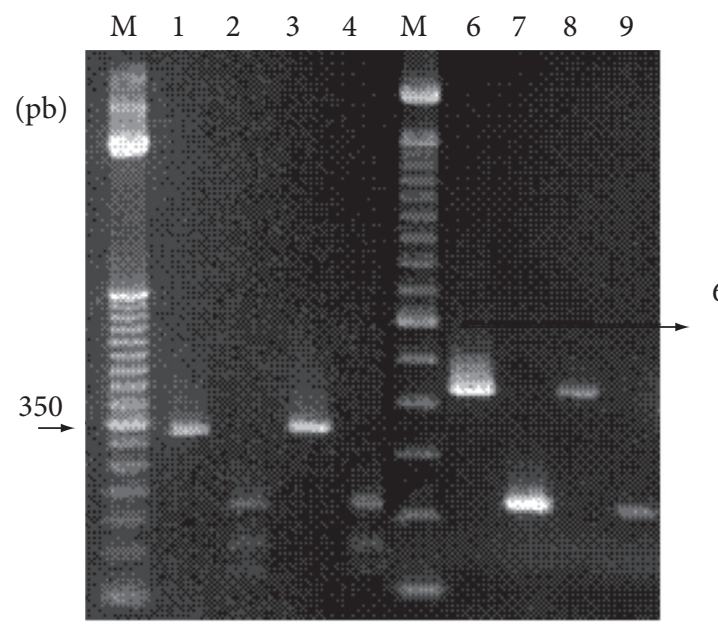

C

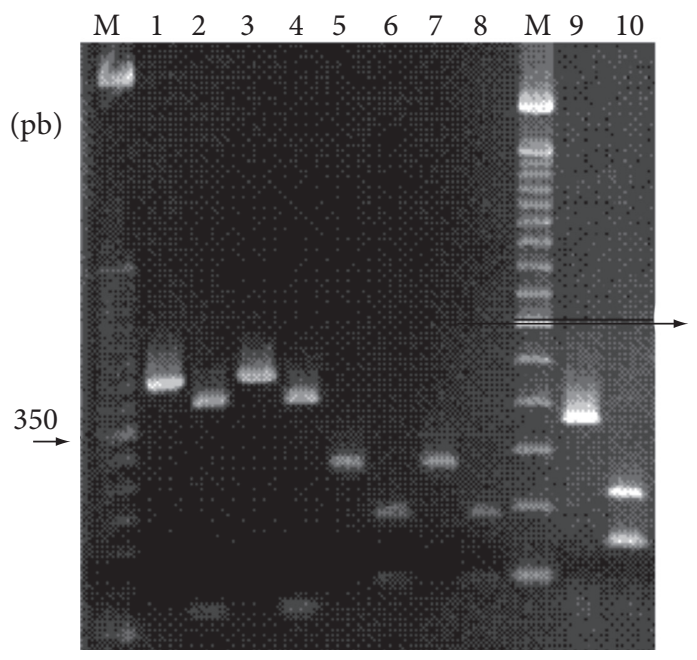

B

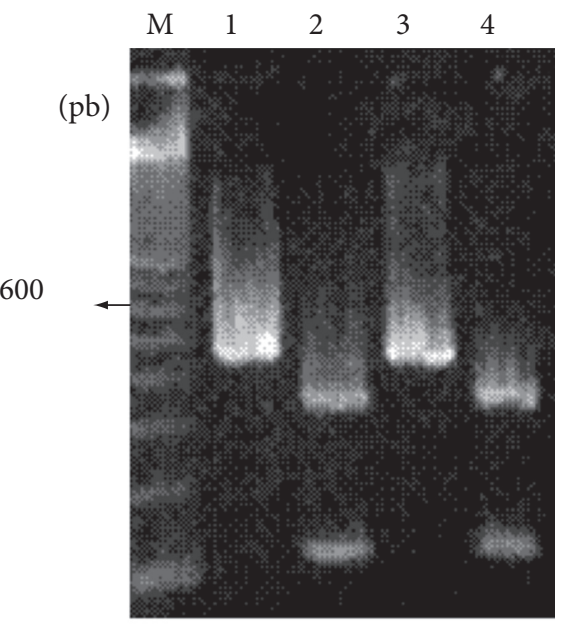

$\mathrm{D}$

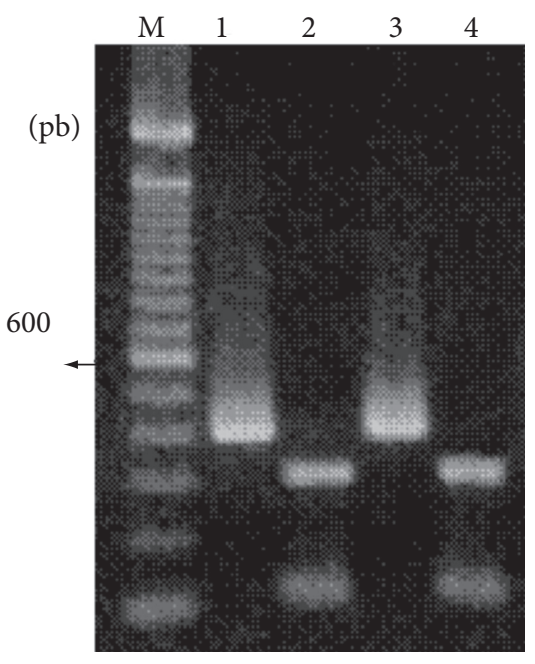

Figura 1. Produto de amplificação da PCR dos genes sed, sej, sei, tst, sec, seh e seg (A, linhas: 1 e 3, gene sed; A, linhas: 6 e 8, gene sej; B, linhas: 1 e 3, gene sei; C, linhas: 1 e 3, gene tst; C, linhas: 5 e 7, gene sec; C, linha: 9, gene seh; D, linhas: 1 e 3, gene seg) e seus padrões de restrição com as enzimas, RsaI (A, linhas: 2 e 4, gene sed; A, linhas: 7 e 9, gene sej; B, linhas: 2 e 4, gene sei; C, linhas: 6 e 8, gene sec; D, linhas: 2 e 4, gene seg) e DraI (C, linhas: 2 e 4, gene tst; C, linha: 10, gene seh).

o gene seg, enquanto em outro paciente, a cepa portava apenas o gene sei, sendo ambas as cepas negativas para a produção das toxinas clássicas SEA-SEE e não portadoras dos genes sea-see. Este fato demonstra que as toxinas mais recentes descobertas como SEG e SEI podem ser responsáveis por casos de intoxicação alimentar em menor frequência.

\section{Conclusões}

A presença de elevado percentual de isolados contendo diferentes genes toxigênicos é preocupante para a saúde do consumidor pela possibilidade de produzirem toxinas responsáveis por intoxicações alimentares. A diversidade genética para os genes se em amostras de Staphylococcus coagulase negativa é um fato importante, pois no Brasil não existe legislação com determinação de limites para Staphylococcus coagulase negativa em alimentos.

\section{Agradecimentos}

Ao Banco do Nordeste do Brasil pelo financiamento do projeto e ao Conselho Nacional de Pesquisa (CNPq) pela bolsa concedida ao primeiro autor. Agradecem também ao Laboratório de Enterotoxinas Estafilocócicas da Fundação Ezequiel Dias (FUNED-MG) e ao Dr. Luiz Simeão do Carmo por ter cedido as cepas padrões FRI (Food Research Institute Madison, Wiscosin, EUA). 


\section{Referências bibliográficas}

ALTSCHUL, S. F. et al. Basic local alignment search tool. Journal of Molecular Biology, v. 215, n. 3, p. 403-410, 1990.

BARBOSA, S. S. et al. Detecção de Staphylococcus sp em queijos de coalho adquiridos em Teresina, PI. In: SEMINÁRIO DE INICIAÇÃO CIENTÍFICA DA UFPI, 13, 2004, Teresina. Anais... Teresina: UFPI, 2004. p. 27.

BECKER, K.; ROTH, R.; PETERS, G. Rapid and specific detection of toxigenic Staphylococcus aureus: use of two multiplex PCR enzyme immunoassay for amplification and hybridization of staphylococcal enterotoxin genes, exfoliative toxin genes, and toxic shock syndrome toxin 1 gene. Journal of Clinical Microbiology, v. 36, n. 9 , p. $2548-2553,1998$.

BERGDOLL, M. S. Staphylococcal food posioning. In: RIEMMAN, H.; CLIVER, D. O. (Eds.). Foodborne infections and intoxications. New York: Academic Press, 1990. p. 85-106.

BRASIL. Ministério da Saúde. Resolução-RDC, no 12 de 2 de janeiro de 2001. Regulamento técnico sobre padrões microbiológicos para alimentos. Diário Oficial [da] República Federativa do Brasil, Poder Executivo, Brasília, 2 de Janeiro de 2001. Secção I, p. 45-53, 2001.

BRASIL. Ministério da Agricultura, Pecuária e Abastecimento. Instrução Normativa 62, de 26 de agosto de 2003. Métodos analíticos oficiais para análises microbiológicas para controle de produtos de origem animal e água. Diário Oficial [da] República Federativa do Brasil, Poder Executivo, Brasília, 18 de Setembro 2003. Seção I, p. 16-17; 36-37, 2003.

CHEN, T. R.; CHIOU, C. S.; TSEN, H. Y. Use of novel PCR primers specific to the genes of staphylococcal enterotoxin $G, H$, I for the survey of Staphylococcus aureus strains isolated from food-poisoning cases and food samples in Taiwan. International Journal of Food Microbiology, v. 92, n. 2, p. 189-197, 2004.

HOFFMANN, F. L.; SILVA, J. V.; VINTURIM, T. M. Qualidade microbiológica de queijos tipo "Minas Frescal", vendidos em feiras livres na região de São José do Rio Preto, SP. Higiene Alimentar, v. 16, n. 96, p. 69-76, 2002.

HUANG, X.; MADDAN, A. Cap3: a DNA sequence assembly program. Genome Research, v. 9, n. 9, p. 68-877, 1999.

JABLONSKI, L. M.; BOHACH, G. A. Staphylococcus aureus. In DOYLE, M. P.; BEUCHAT, L. R.; MONTVILLE, T. J. (Eds.). Food Microbiology Fundamentals and Frontiers. Washington: American Society of Microbiology Press, 1997. p. 353-375.
JORGENSEN, H. J. et al. Enterotoxigenic Staphylococcus aureus in bulk milk in Norway. Journal of Applied Microbiology, v. 99, n. 1, p. 158-166, 2005.

LONCAREVIC, S. et al. Diversity of Staphylococcus aureus enterotoxin types within single samples of raw milk and raw milk products. Journal of Applied Microbiology, v. 98, n. 2, p. 344-350, 2005.

FRITSCH, E. F.; MANIATIS, T.; SAMBROOK, J. Molecular cloning: a laboratory manual. New York: Cold Spring Harbor Laboratory, 1989. 235 p.

NORMANNO, G. et al. Coagulase-positive staphylococci and Staphylococcus aureus in food products marketed in Italy. International Journal of Food Microbiology, v. 98, n. 1, p. 73-79, 2005.

OMOE, K. et al. Detection of seg, seh and sei genes in Staphylococcus aureus isolates and determination of the enterotoxin productivities of S. aureus isolates harboring seg, seh or sei genes. Journal of Clinical Microbiology, v. 40, n. 3, p. 857-862, 2002.

RODRIGUES, L. A. et al. Selective enterotoxin production in foods by Staphylococcus aureus strains that produce more tham one enterotoxin. Journal of Food Protection, v. 56, n. 6, p. 538-540, 1993.

ROSEC, J. P.; GIGAUD, O. Staphylococcal enterotoxin genes of classical and new types detected by PCR in France. International Journal of Food Microbiology, v. 77, n. 1-2, p. 61-70, 2002.

SÁ, M. A. R. et al. Perfil microbiológico do queijo minas frescal comercializado no município de Uberlância-MG. Higiene Alimentar, v. 17, n. 104-105, p. 169-173, 2003.

SENA, M. J. Perfil epidemiológico, resistência a antibióticos e aos conservantes nisina e sistema lactoperoxidase de Staphylococcus sp. isolados de queijos coalho comercializados em Recife-PE. 2000. 75 p. Tese (Doutorado em Ciência Animal) - Universidade Federal de Minas Gerais, Belo Horizonte, 2000.

SU, Y. C.; WONG, A. C. L. Current Perspectives on Detection of Staphylococcal Enterotoxins. Journal of Food Protection, v. 60, n. 2, p. 195-202, 1997.

SU, S. et al. Characterization of staphylococcal bovine mastitis isolates using the polymerase chain reaction. Journal of Food Protection, v. 61, n. 10, p. 1384-1386, 1998.

VERAS, J. F. et al. Levantamento de surtos de toxinfecção alimentar envolvendo leite e produtos derivados no estado de Minas Gerais, Brasil. Higiene Alimentar, v. 17, n. 104-105, p. 218, 2003. 